\title{
El legado de Juan Ramón Jiménez en Moguer
}

\author{
Centro de Estudios Juanramonianos \\ URL de la contribución <www.iaph.es/revistaph/index.php/revistaph/issue/view/4253>
}

\section{RESUMEN}

La presencia del autor de Platero aún se hace patente en cada calle, en cada rincón y en cada esquina de su pueblo, Moguer. Hacia 1947, a iniciativa de un grupo de moguereños, se decide homenajear al poeta en el exilio creando una biblioteca pública con su nombre. En 1955, se complementa con un espacio expositivo dedicado al poeta. El matrimonio Jiménez, ilusionado con el proyecto, colabora activamente en la dotación de contenido. El 14 de noviembre de 1958 abre oficialmente al público sus puertas la casa museo.

La casa museo inicia su singladura como espacio museográfico, convirtiéndose en el eje vertebrador de la visita turística a Moguer. En ella se preserva todo el patrimonio que el poeta decide legar a su pueblo: su biblioteca personal de la etapa madrileña, su colección de revistas y periódicos, enseres personales, etc., elementos gracias a los cuales el visitante, al recorrer sus estancias, puede evocar ese Moguer en el que Juan Ramón Jiménez escribió la mayor parte de su producción literaria.

Hoy, el museo se presenta no solo como espacio de contemplación, sino como un instrumento multifuncional, y como eje vertebrador de propuestas en el marco de creación literaria, cultural, pedagógica y turística.

Moguer abarca un conjunto patrimonial imbricado tanto en la vida como en la obra de su poeta. Conocer a Juan Ramón es conocer Moguer. Y conocer Moguer es conocer a Juan Ramón.

\section{Palabras clave}

Casa Museo Zenobia-Juan Ramón Jiménez | Juan Ramón Jiménez | Moguer (Huelva) | Zenobia Camprubí | 


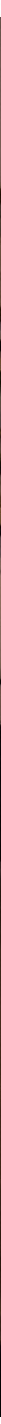

Despacho principal | foto Salvador Aguilar (Fototeca del Centro de Estudios Juanramonianos, titular de todas las imágenes que ilustran este texto) 
1

La casa situada en la Calle Juan Ramón Jiménez n. 10 continúa siendo en la actualidad la sede del museo y de la Fundación Zenobia-Juan Ramón Jiménez.

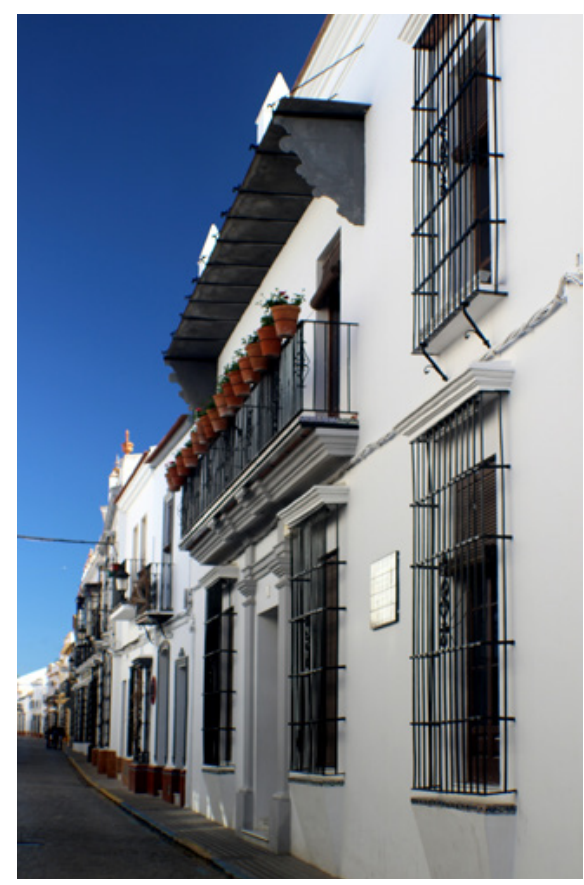

Fachada de la Casa Museo Zenobia-Juan Ramón Jiménez | foto José Manuel Millán
"Moguer, la blanca maravilla, la luz con el tiempo dentro..." (JIMÉNEZ, 2006). Así describía el poeta su pueblo natal, al que llevó durante toda su vida en forma de piedras en su bolsillo, muy cerca del corazón, para no perder el arraigo y la fuerza de su tierra (JIMÉNEZ, 1961). A pesar del paso de los años, la presencia del autor de Platero aún se hace patente en cada calle, rincón y esquina del municipio. Gracias a Juan Ramón, Moguer se universalizó y aún hoy son muchos los que acuden a su pueblo natal en busca de la tácita presencia del Nobel, queriendo ilustrar con imágenes lo que describe magistralmente a través de su obra.

Años antes de que fuese galardonado con el Premio Nobel, en 1947, a iniciativa de un grupo de moguereños, se decide homenajear al poeta en el exilio creando una biblioteca pública con su nombre (INAUGURACIÓN, 1947: 10). En 1955, se complementa con un espacio expositivo dedicado al poeta, que, a elección del autor, se ubicó en la casa familiar donde vivió desde sus cinco años ${ }^{1}$ y cuyas menciones son muy numerosas en sus Elegías andaluzas. También por expreso deseo de Juan Ramón, el nuevo museo se denominaría Casa Museo Zenobia Juan Ramón Jiménez, en homenaje también a su compañera de vida y, gracias al impulso y las gestiones del entonces alcalde de Moguer y diputado provincial, Juan de Gorostidi, la Diputación Provincial de Huelva adquiere el inmueble. El matrimonio Jiménez, ilusionado con el proyecto, colabora activamente en la dotación de contenido con varios envíos y da indicaciones para que casi todos los fondos que se conservaban en el Museo Romántico de Madrid, procedentes del piso de la calle Padilla -que tuvieron que dejar en la salida a su exilio en agosto de 1936fueran a Moguer. Además, destinan la mitad de la dotación económica del Premio Nobel al museo. El 14 de noviembre de 1958 abre oficialmente al público sus puertas la casa museo, tal y como se publica en el diario provincial Odiel Información (FLERY, 1958: 5-6).

La casa museo inicia su singladura como espacio museográfico, convirtiéndose en el eje vertebrador de la visita turística a Moguer. En ella se preserva todo el patrimonio que el poeta decide legar a su pueblo: su biblioteca personal de la etapa madrileña, su colección de revistas y periódicos, enseres, etc., elementos gracias a los cuales el visitante, al recorrer sus estancias, puede evocar ese Moguer en el que Juan Ramón Jiménez escribió la mayor parte de su producción literaria de la etapa española como Platero y yo, Elegías Andaluzas, Apartamiento, Baladas de primavera, Las hojas verdes...

En el año 2000 el inmueble sito en la calle Nueva debe ser cerrado al público para acometer labores de restauración, a la vez que se decide dar un giro y renovar el discurso museográfico adaptándolo a los nuevos tiempos (RAMÍREZ ALMANZA, 2006). De forma provisional, se habilita otro de los espacios juanramonianos de Moguer, la casa donde Juan Ramón Jiménez 


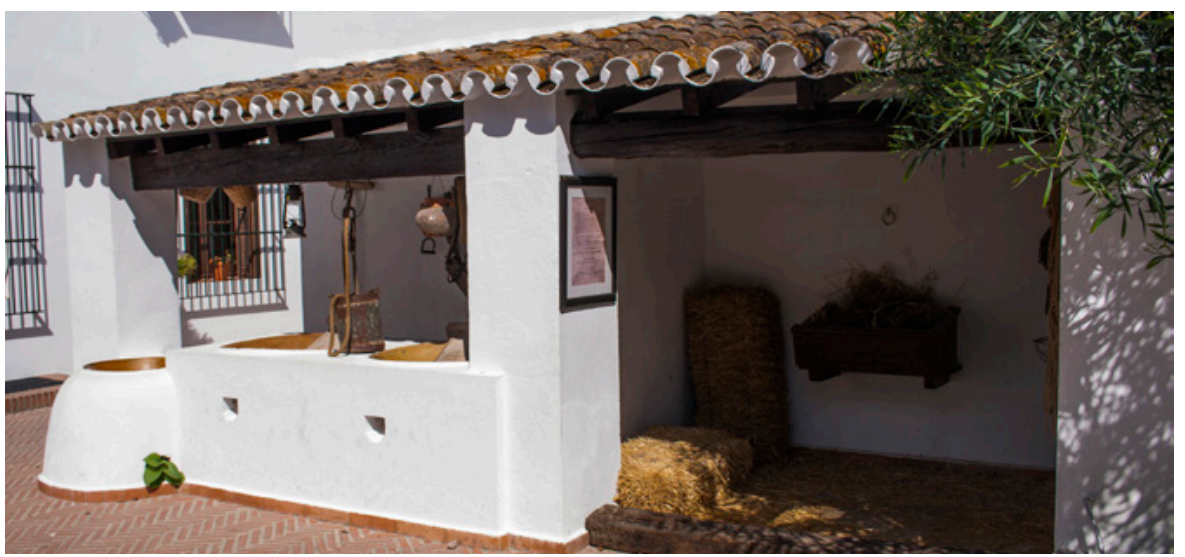

Corral y cuadra de Platero | foto Salvador Aguilar

nace, situada en el barrio de pescadores, en la calle Ribera, para que el legado continuase a disposición del visitante (JIMÉNEZ FERNÁNDEZ, 2006). Son años en los que se trabaja en la rehabilitación del espacio del poeta por excelencia, la casa museo, desarrollándose nuevos discursos museográficos y una nueva ordenación de los fondos del legado juanramoniano (BEJARANO ÁLVAREZ; RODRÍGUEZ DOMÍNGUEZ, 2006).

En diciembre de 2007, concretamente el 26, modernizadas las instalaciones museísticas, puesta al día la gestión y organizadas y digitalizadas todas las colecciones que alberga, abre sus puertas una remozada casa museo que en conjunto ofrece diferentes ámbitos de actuación, concebidos bajo una estructura más innovadora. Se ofrece una nueva visión que, sin perder el sabor de los espacios en los que vivió el poeta, introduce al público en una dimensión lírica, de evocación y conocimientos. Se presenta no solo como espacio de contemplación, sino como un instrumento multifuncional, y como eje vertebrador de propuestas en el marco de creación literaria, cultural, pedagógica y turística (RODRÍGUEZ DOMÍNGUEZ; MUÑOZ MORENO; BEJARANO ÁLVAREZ et ál., 2007).

La rehabilitación de la Casa Museo Zenobia Juan Ramón Jiménez permitió la ampliación de sus salas y asumir nuevas funciones de programación o actividades. Es un nuevo espacio creativo y cultural, donde se entrecruzan los planteamientos tradicionales junto a otros espacios que interpelan al mundo de las nuevas tecnologías multimedia. Se ha articulado otra imagen del legado a difundir.

Como mayoritariamente su público procede del ámbito educativo, el nuevo entorno se pensó como un instrumento pedagógico, intentando llegar a él con aplicaciones didácticas (guías pedagógicas, aulas especiales, talleres literarios, etc.). La casa se concibe como un espacio pedagógico donde cohabita la cultura didáctica de forma recreativa y lúdica.

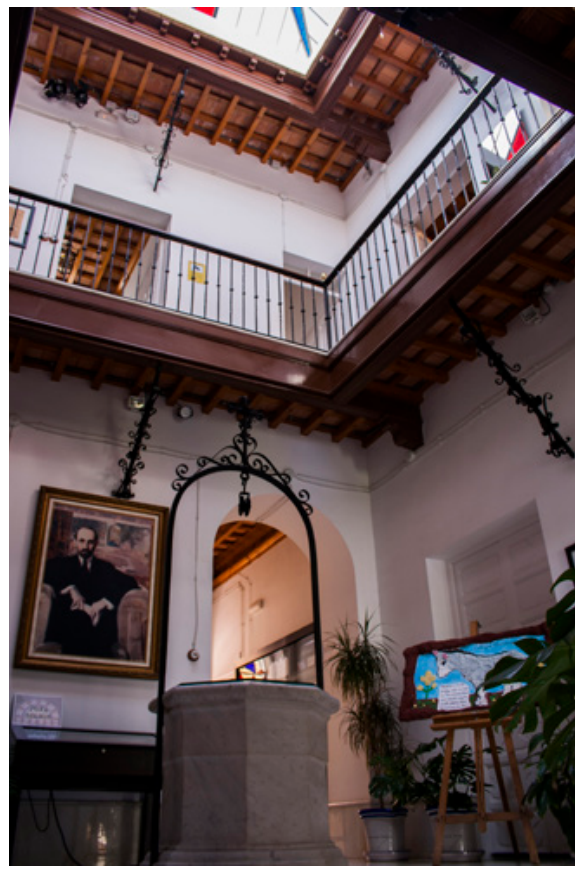

Interior Casa Museo Zenobia-Juan Ramón Jiménez | foto Salvador Aguilar 


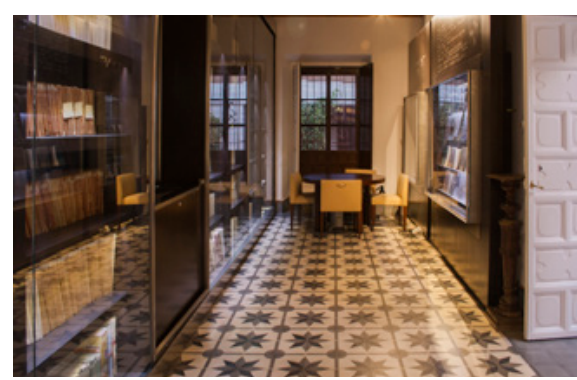

Hemeroteca personal de Juan Ramón Jiménez | foto Salvador Aguilar
2

Espacio web Año Platero <http://www. aytomoguer.es/es/ano-platero/> [Consulta: 21/09/2018]
Uno de los aspectos más importantes de la casa museo, al margen de su sentido de espacio visitable, es el legado que alberga, sus fondos puestos a disposición del investigador. Se articula como un espacio de investigación que tiene como fin último el acercamiento de la cultura bajo el aspecto de la exposición y de la consulta bibliográfica. Uno de los pilares fundamentales para esta faceta ha sido la creación del Centro de Estudios Juanramonianos, centro de documentación en torno a las figuras de Zenobia y Juan Ramón Jiménez, que se encarga de recuperar, adquirir, analizar, custodiar, conservar y difundir todo el patrimonio documental y bibliográfico existente en sus instalaciones.

Resultaría difícil entender hoy cualquier plan turístico de Moguer sin la presencia de la casa museo, no sólo por su faceta como garante del legado juanramoniano y espacio visitable, sino porque todo el municipio conforma el ámbito de creación del poeta. Moguer abarca un conjunto patrimonial imbricado tanto en la vida como en la obra de su poeta. Conocer a Juan Ramón es conocer Moguer, conocer la provincia de Huelva. Y conocer Moguer es conocer a Juan Ramón. Entendemos que ambos, en su universalización literaria e histórica, nos llevan a una oferta turística y cultural de primer nivel.

La promoción turística y cultural de la Casa Museo Zenobia Juan Ramón Jiménez no está exclusivamente en la casa donde vivió, contemplar sus pertenencias personales, muebles, enseres, libros, documentos... Juan Ramón Jiménez ofrece a través de su obra un paisaje, un ambiente, la traza de un Moguer descrito, vivido, con una atmósfera de tiempo y personajes latentes en un pueblo que puede ofrecer lo material e inmaterial del andaluz universal.

Desde el año 2014 en que se celebró el centenario de la primera edición de Platero y yo, se estructuró además una ruta por el patrimonio monumental y literario juanramoniano que se extendió por diferentes espacios de la localidad. Se crea un pasaporte del Año Platero, con el que se insta al visitante a recorrer todo el patrimonio juanramoniano e ir completando etapas para conseguir al final de ellas una edición conmemorativa de dicha obra. En ese recorrido se incluyen espacios como la casa natal de la calle Ribera, la visita al cementerio donde descansan los restos del matrimonio Jiménez, y a monumentos singulares como el monasterio de Santa Clara o la parroquia Nuestra Señora de la Granada. Además, se crea un museo al aire libre, Platero EsCultura, ubicando esculturas de personajes del inmortal Platero como Aguedilla, Darbón, el Tío de las vistas o Platero, en diferentes lugares estratégicos de su casco histórico².

Gracias a esta perfecta simbiosis entre la obra y los lugares donde el poeta desarrolla su actividad creadora, Moguer se ha convertido en el principal referente y epicentro del patrimonio material e inmaterial juanramoniano. 


\section{BIBLIOGRAFÍA}

- BEJARANO ÁlVAREZ, R.; RODRÍGUEZ dOMíngueZ, T. (2006) Juan Ramón Jiménez, su biblioteca personal. Revista Mi biblioteca, n. ${ }^{\circ}$ 7, 2006, pp. 22-28

- FLERY (1958) La Casa Zenobia y Juan Ramón de Moguer abre sus puertas al público. Odiel Información, 18 de noviembre de 1958, pp. 5-6

- INAUgURACIÓN de la nueva biblioteca municipal de Moguer (1947) ABC. Edición de Andalucía, 12 de octubre de 1947, p.10

- JIMÉNEZ, J. R. (2006) Nubes sobre Moguer. Leyenda (1896-2006). Madrid: Visor, 2006

- JIMÉNEZ, J. R. (1961) La Corriente infinita. Crítica y evocación. Madrid: Aguilar, 1961

- JIMÉNEZ FERNÁNDEZ, C. (2006) Un paseo por la casa natal del padre de Platero y yo. Revista Mi biblioteca, n. ${ }^{\circ} 7$, 2006, pp. $16-21$

- RAmírez ALMANZA, A. (2006) Síntesis del proyecto museográfico para la Casa-Museo Zenobia-Juan Ramón Jiménez. Revista Montemayor, 2006, pp. 36-43

- RODRÍGUEZ DOMíNGUEZ, T.; MUÑOZ ROMERO, R.; BEJARANO ÁLVAREZ, R.; GONZÁLEZ ZAPATERO, M. (2007) Casa Museo Juan Ramón Jiménez-Zenobia Camprubí Moguer, Huelva. En III Encuentro Internacional Actualidad en museografía. Mérida, 24-26 de septiembre de 2007. Madrid: ICOM-España, 2008, pp. 61-83 